\title{
CORRIGENDUM
}

\section{A unified definition of clinical resistance/intolerance to hydroxyurea in essential thrombocythemia: results of a consensus process by an international working group}

G Barosi, C Besses, G Birgegard, J Briere, F Cervantes, G Finazzi, H Gisslinger, M Griesshammer, L Gugliotta, C Harrison, $\mathrm{H}$ Hasselbalch, E Lengfelder, JT Reilly, JJ Michiels and T Barbui

Leukemia (2007) 21, 1136. doi:10.1038/sj.leu.2404665

Correction to: Leukemia (2007) 21, 277-280.

doi:10.1038/sj.leu.2404473

It has been identified by the authors that there is an error in Table 2.
The correct Table 2 is shown below:

The authors apologize for any inconvenience caused.

Table 2

Platelet count $>600000 \mu \mathrm{l}$ after 3 months of at least $2 \mathrm{~g} /$ day of $\mathrm{HU}(2.5 \mathrm{~g} /$ day in patients with a body weight $>80 \mathrm{~kg})$

Platelet count $>400000 \mu \mathrm{l}$ and WBC less than $2500 \mu \mathrm{l}$ at any dose of $\mathrm{HU}$

Platelet count $>400000 \mu \mathrm{l}$ and $\mathrm{Hb}$ less than $10 \mathrm{~g} / \mathrm{dl}$ at any dose of $\mathrm{HU}$

Presence of leg ulcers or other unacceptable muco-cutaneous manifestations at any dose of $\mathrm{HU}$

HU-related fever

Abbreviations: ET, essential thrombocythemia; HU, hydroxyurea; WBC, white blood cells. 